\title{
URBAN SPRAWL AND SUSTAINABLE CITY DEVELOPMENT IN NIGERIA
}

\author{
Rosemary Nnaemeka-Okeke ${ }^{1}$ \\ 1 Department of Architecture, Caritas University Enugu, 400001 Enugu, Nigeria, e-mail: Rosenna90@gmail.com
}

Received: 2016.02.02

Accepted: 2016.03.04

Published: 2016.04.01

\begin{abstract}
Urban environmental problems are of different dimensions and are mostly due to geologic, climatic and cultural factors. However, the cultural factors seems to be more pronounced in the Nigerian context because most of the identified urban environmental issues are so much associated with the way of life of the people, either as reactions to urbanization or their spatial heritage. Their effects are far reaching on efforts to attain sustainable development in the country. Since no section of the country's urban environment is immune to environmental effects, there is urgent need to seek workable solutions by the application of planning, economic, legal, institutional and educational tools as have been suggested here.
\end{abstract}

Keywords: urban city renewal, architecture, Nigerian environment, climate change.

\section{INTRODUCTION}

The major urban challenge of the twenty-first century includes the rapid growth of many cities and their role in causing or mitigating climate change. Evidence from around the world suggests that urban planning has failed to address these challenges. Urban sprawl and unplanned urban development are among the most visible consequences, along with the increasing vulnerability of hundreds of millions of urban dwellers to rising sea levels, coastal flooding and other climate-related hazards. The world is increasingly becoming urbanized and the rate at which city populations grow and the rate at which countries urbanize is an indicative of the pace of social and economic change [Donk 2006]. In 1976, onethird of the world population lived in cities and 30 years later (in 2006), this rose to one-half of the entire humankind [Tibajuka 2006]; and by the target year for the Millennium Development Goals (MDGs), which is by 2050, cities in the world are estimated to grow to two-third, or 6 billion people by 2050 [UN Habitat 2006].

The development of these cities has given rise to concerns about their sustainability. Most of the big African cities; including those in Nigeria are faced with the problem of rapidly de- teriorating physical and living environment. This deterioration manifests itself in a form of slums, urban sprawl and squatters' settlements, increasing traffic congestion, flooding, erosion, and deteriorating infrastructure. The increase in urban sprawl in most cities continues to attract attention of national and international agencies but the efforts has not yet achieved much result at checking the sprawl.

There is the need therefore, to re-evaluate these efforts and make necessary suggestions that would reverse this trend. In the realization of this objective, this research paper proposes a planning strategy that addresses the problems of urban sprawl in Nigeria. It will examine urbanization trends in Nigeria. Stating the characteristic features of urban sprawl in Nigerian cities and also, examine the efforts puts in place in the past to address this problem. Considering the limitations of these efforts, this paper finally suggests a feasible strategy which is adaptive to African socio-cultural milieu for the management of urban sprawl in Nigerian cities.

Urban Sprawl is directly identified with urban growth - as cities get bigger, they expand around their peripheries. But sprawl is more specific as it is defined as an 'uncoordinated growth': the expansion of a community without concern for 
consequences or environmental impact. It can be defined as the scattering of new development on isolated tracts, separated from other areas by vacant land [Lata, et al. 2001]. It often involves the construction of residential and commercial buildings in rural areas or otherwise undeveloped land at the outskirts of a city. Omole F.K (2000) defined Urban sprawl as a formless dispersal of congested urban area with little or no regard for the inter-relationship of such factors as transportation, employment, health, and recreational needs. It has also been described as leapfrog development [Jothimani, 1977]. Urban sprawl is characterized by an unplaned and uneven pattern of growth, driven by multitude of processes and leading to inefficient resource utilization. It has become a pejorative term without any serious examination of its qualities or benefits and without any critical analysis of its troubled alternative - urban congestion while the formation of the world's cities has always been determined by the means of available transport.

Sustainable development refers specifically to "development that meets the needs of the present without compromising the ability of future generations to meet their own needs" [The World Commission on Environment and Development. 1987]. Sustainable development implies economic growth, together with the protection of environmental quality, each reinforcing the other. The importance of this form of development is a stable relationship between human activities and the natural world, which does not diminish the prospects for future generations to enjoy a quality of life at least as good as our own. There is a need therefore to achieve economic and social development in ways that do not exhaust a country's natural resources. This is where sustainable development comes to play.

Wheeler, in his 1998 article, defines sustainable urban development as "development that improves the long-term social and ecological health of cities and towns" sustainable city development can be characterized by compact, efficient land use; less intense automobile use, yet better access; efficient resource use; less pollution and waste; the restoration of natural systems; good housing and living environments; a healthy social ecology; a sustainable economy; community participation and involvement; and preservation of local culture and wisdom. Some planners argue that modern lifestyles use too many natural resources, thereby polluting or destroying the eco- system, creating urban heat islands, and causing climate change. Many urban planners, therefore, advocate for sustainable cities. In a Sustainable City, the use of renewable resources is emphasized, resource consumption is minimized and resources are managed in a way that maximizes recovery and reuse.

\section{EMERGENCE AND TRENDS OF URBAN SPRAWL: CASES IN NIGERIA}

Urban sprawl is becoming a major feature of the developing countries with nearly all global demographic growth that is mostly concentrated in developing countries. Nigeria, as a nation, has been experiencing an accelerated shift of her populations from rural to urban areas. This rapid rate of urbanization has engendered several challenges and problems, similar to situations in other parts of the world. The problems identified in Agenda 21 are prevalent in Nigeria. Today's Nigerian city, according to Mabogunje (2002) is typified by substandard and inadequate housing, slums, and lack of infrastructure, transportation problems, low productivity, poverty, crime and juvenile delinquency. Urbanization, according to him is the root cause of the high rates of environmental degradation, pollution and social delinquency. Nigeria ranks $151^{\text {st }}$ on the Human Development Index of 177 countries worldwide [HDR, 2004].

The need for monitoring urban development has become imperative to help curb the problems of this type of growth. Monitoring urban development is mainly to find the type, amount and the location of land conversion for future planning [Shekhar, 2001]. Urban sprawl varies in degrees between the developed and the developing world and subsequently they have differing consequences. For most developing countries such as Nigeria, the governance and management of their towns and cities are most discouraging as the cities appear to be growing beyond the control of planners, beyond management capacities and beyond available resources [Agbola and Olurin 1998]. Since man's quest for change will continue within his dynamic environment, this points to the fact that urbanization becomes an inevitable phenomenon particularly in developing countries.

Contemporary comparative international experiences do show that the problems have to be approached with innovative ingenuity and solved 
through novel strategies which are consensual and adaptive to the socio-economic and cultural setting of the target population. A close look at most Nigerian cities reveals that ethnicities and identities are reinforced because most city-dwellers are, to some extent, enclosed within their own ethnic network, which serves as a partial barrier between them and the wider social system. The sharp cultural differences among many groups further hamper the development of an inter-ethnic sense of community. It is also observed that ethnic identity and ethnic conflicts are often greater in the cities than in the rural areas. Rouch sees this as a product of the interaction among peoples of different cultures rather than weakening ethnic pride and cohesions, the city or urban life tends to increase them. The greater the fear by one group of being dominated the greater the emphasis on their own culture. Immigrants living in cities other than their own "native towns or villages" at times manipulate their own cultural tradition - fostering retribalization - in order to develop informal political associations which can serve as organizational weapons in contemporary political struggles.

Despite the changes that have taken place since colonialization, the boundaries between ethnic groups have been able to retain, or resume, great significance. Indeed, the perceived distinctions among ethnic groups are often as sharp as the distinction most Americans make between blacks and whites. Thus, ethnicity may be considered Nigeria's equivalent of the "American dilemma". It affects where one lives, with whom one associates, for whom one votes, at what occupation one works, and so forth. For these reasons a typical Nigerian city exists as a cluster of partly overlapping ethnic enclaves, each with a somewhat distinct set of perspectives and practices. Lagos, Kano and Port Harcourt show three categories of ethnic membership. Other cities, depending on their level of urbanization, demonstrate this to a lesser degree. Nigerian towns are now clearly the "motors of development", the main agents of social change. Town life is identified with the idea of progress - a rejection of the "totalitarian rural and village tradition". To the many migrants who flock to the cities from the rural centers - whether armed at times with high school or even college certification, or unskilled labor in search of almost nonexistent jobs - city life is seen as an "escape from the traditional rural life" which simultaneously absorbs clutches and emasculate. To this set of migrant, the urban superstructure has real value as a refuge.

Urbanization is a positive force in development. Cities and towns are home to most industry, commerce, and services, all of which can be highly productive. Over the decade 1984-1994, non-oil firms in urban areas accounted for half of Nigeria's Gross Domestic Product. Per capita incomes in towns and cities are roughly a third higher than in rural areas. Nigeria's urban population, over the period 1980-1993, grew at an astonishing 5.5 percent a year, compared with 2.9 percent nationwide. Many urban Nigerians, however, do not earn enough to cover even basic needs. An estimated 21 percent or so ( 8.5 million people) were below the poverty line in 1992-1993. They, more than anybody, suffer from the breakdown in urban infrastructure, especially through poor health. Most of the burden falls on women and children. Urban pollution and poor management of municipal waste (sewage and refuse) add to the health hazards. Numerous industries, from pulp to petroleum, dump untreated and often toxic liquids in open gutters, streams, rivers, and lagoons. And, as elsewhere, motor vehicles contaminate the air, land, and water.

\section{URBAN SPRAWL AND SUSTAINABLE CITY DEVELOPMENT IN NIGERIA THE JOURNEY SO FAR}

Microsoft Encarta (2005) gives the definition of urban sprawl as the outward spread of built up areas caused by their expansion. The expansion of the urban area is towards its country-side that surrounds it. The urban sprawl is believed to be one of the by-products of urbanization. Cities are generally regarded all over the world as providing the engines of economic development both for the cities themselves and their surrounding rural hinterland [UN-Habitat 2004]. This is the major reason why cities are regarded as depots of opportunities for the urban dwellers to exploit for their economic and social development; as well as magnetic poles that attract rural dwellers via rural-urban migration from their surrounding rural hinterland. Without any doubt, an urban center (city) would only serve as the engine of development if it is economically healthy, properly planned and managed in a way that would allow for efficient and functioning operations of infrastructural facilities among others. Otherwise, it 
can truly be drag on economic development [Ravallion 2001].

Due to uncontrolled urbanization, one major feature of Nigerian cities is urban sprawl. The urban sprawl is characterized by haphazard housing development in the urban suburbs, where majority of the structures are without planning permit in uncoordinated layouts. Oftentimes, these structures are a product of squatters that choose to settle at the suburbs as a result of their inability to afford residential accommodation in the city. Improper coordination of the physical development promotes high level of inaccessibility within the area. The area lacks essential social and welfare infrastructure like water, electricity, health care and educational facilities among others. The unsanitary conditions in the area pose a continuous threat to healthy living of the inhabitants and it is an area regarded as an area that is dangerously unsafe for living because of its associated social vices. Above all, urban sprawl presents a repulsive outlook of the city space that calls for re-planning.

Unfortunately, there is no Nigerian city that can be exonerated from the stigmatization of urban sprawl. This has prompted Farunkanmi (2003), to draw the attention of town planners to the implications of sprawling city that if governing authorities fail to inject the essential infrastructural facilities, such neglect would pose serious and dangerous implications for human health, progress and development. From the discussion so far, urban sprawl poses a lot of challenges to town planners, city managers, governments and stakeholders. It becomes expedient to identify the causes or factors responsible for urban sprawl in Nigerian cities.

\section{FACTORS RESPONSIBLE FOR URBAN SPRAWL IN NIGERIAN CITIES}

Different factors are responsible for urban sprawl in Nigerian cities. The unprecedented increase in the population in the Nigerian cities continues to put pressure on the existing housing facilities. The inability of the housing delivery to cope effectively with the housing need has resulted in pricing out the majority of the low incomeearners from the housing market. Most affected groups are the immigrants from the rural hinterland that prefer to settle at the suburbs of the cities. Often times, this is responsible for the devel- opment of squatter's settlement at the periurban zones [Olujimi and Gbadamosi 2007].

Cities present unlimited socio-economic opportunities, particularly in the area of landed property development. The operations of the economic forces in the supply of land for commercial development within the city center are encouraging the suburb of the city for residential property development. This has sufficiently propelled the greed for land speculation and hoarding at the suburbs. Hence, most of the layouts are not linked to others for accessibility purposes. Another factor that is responsible for the promotion of urban sprawl is the inability of government to effectively develop their compulsorily acquired parcels of land in some cities. This is predicated on the nonreadiness of government to pay compensations on un-exhausted resources in the acquired land to the owners. Thus, the unwillingness of the owners to release fully the acquired land to government and their continuous disposal of the land to individuals that continues to develop the land without reference to the planning authorities to seek planning permission. However, the planning authorities are expected to control physical development in all parts of the city (including the sprawling areas) but the ineffectiveness of the development control tool at putting such sprawl at bay is hindered by a lot of factors. These among others include lack of political will to implement development control measures, insufficient planning staff to carry out effective monitoring, and lack of equipment, such as development control monitoring vehicles. In spite of the shortcomings, efforts are being made at different quarters to check the sprawling growth of Nigerian cities. These efforts are examined in the next section of the paper with a view to highlighting the limitations as to serve as guides in suggesting new strategy.

Urbanization and its attendant problems have constituted huge challenges to the received knowledge, (both in theory and in practice) in urban planning and management. The appropriateness of conventional urban planning approach to the improvement of urban environmental conditions in the face of deteriorating urban environment have often been questioned (Agbola 2006). It became imperative to search for new concepts for the emancipation of low income urban communities.

In this respect therefore, United Nations Development Programme (UNDP) and United Nations Centre for Human Settlement (UNCHS) 
have subsequently initiated strategies to evolve a participatory approach to the development and management of urban environment hinged on the principle of sustainable development [Ogu 2000]. Popular among this is the Sustainable City Programme (SCP) which promotes a positive vision where all humans have adequate shelter, healthy and safe environment, basic services and freely chosen employment. It also places strong emphasis on gender equality, partnership and good urban governance. In Nigeria, the Sustainable City Project (SCP) was first applied in Ibadan, i.e. Sustainable Ibadan City Project (SICP) in 1992; and subsequently replicated in Kano and Enugu while the Sustainable Ibadan City Project had been abandoned due to non-readiness of the major stakeholders (Oyo state government and the local government council authorities) to contribute their counterpart funding and the projects at Enugu and Kano have only started with skeletal ground works. Ever before the introduction of Sustainable City Project in Nigeria, significant efforts had been made at redressing urban decay, particularly at the core area in Nigerian cities in a form of urban renewal programme but this was not extended to the urban sprawl at the peripheries of the Nigerian cities. This is because urban sprawl had not been seen as physical development problem that needs special focus except in a form of preparing a master plan for the existing settlement, a project that is believed to take care of the sprawling growth of the settlement in question. Besides the fact that not many cities and towns can boast of having master plan, the few cities and towns with master plan had become obsolete without any significant efforts to get them reviewed. Disappointedly, the few cities and towns with current master plan suffer the non-political will to implement/effect the development control measures that could check urban sprawl [Olujimi and Fashuyi, 2004].

The cases of contravention in Abuja as analyzed are not unique. They are features of the planning experience in other towns and cities in Nigeria, where growth is rapid and development control cannot cope with pressures of the development. Examples of these cities are Lagos, Enugu, Kaduna, Kano, Benin, Ibadan and Akure amongst others. However, the implementation of the Abuja mater plan under the administration of the former president Olusegun Obasanjo (1999 May 2007) controlled physical development in the city in spite of the political obstacles intro- duced by the previous administrations at bastardizing the master plan [Kalgo and Ayileka 2001; Olujimi and Ayeni 2006].

Another effort at checking urban sprawl in Nigeria is the use of the provisions of the Nigerian Land Use Act of 1978. One of the objectives for the promulgation of the Nigerian Land Use Act in 1978 was to check urban sprawl and land speculation [Federal Government of Nigeria (FGN), 1978]. The law, amongst others, gives power to the government at three different levels (Federal, State and Local government) to compulsorily acquire land within their areas of jurisdiction for development in the overall interest of the people. The Act, however, provides for the payment of compensation for the existing development on the acquired land and not for undeveloped land. The implementation of the Act continues to witness hindrance because of the failure on the part of the government for not recognizing the cultural rights of the land-owners.

Even when land acquisitions are made by governments, their non-readiness to pay compensation to land-owners prompts owners of the land pronounced as acquisition to take-over and disposes such parcel of land illegally to individual developers. The developers now develop their land without any recourse to the Area Urban and Regional Planning Office yet the planning office feels unconcerned believing that they are illegal developments on government acquisitions. The non-readiness of the government to pay compensation cannot be attributed to non-availability of funds but to a lack of interest in attaching priority to such projects in terms of budgetary allocation and disbursement of funds. Rather than serving as check on the development of urban sprawl, the activities of the land-owners succeed in promoting urban sprawl.

Under the State Urban Development Programme in 1985, each of the 36 State governments in Nigeria acquired and paid full compensation on the acquired parcels of land at different locations in their respective state capitals. The objectives of the programme, amongst other, is to improve institutional structures at the state and local levels and to strengthen urban management systems for financing, delivery and maintenance of public services and infrastructure and to improve the living conditions of the urban poor population through the physical improvement (upgrading) of communities in greatest need and the development of serviced land for low-in- 
come groups [DHV Consulting Engineers 1985]. The acute housing shortage in all the state capitals prompted the State governments in Nigeria to embark on the sites and services project as a means to improve directly on the housing delivery but to check indirectly the problem of urban sprawl. Disappointedly, most of the locations selected for the project suffered low patronage due to the far distances of the project sites to the developed parts of the cities where the projects are sited [Onibokun 1997]. In spite of these efforts, cities in Nigeria are ridden with urban sprawl and this calls for people-oriented strategy at addressing the problem of urban sprawl.

\section{A SUGGESTED PLANNING STRATEGY}

The problem of urban sprawl cannot be regarded as devoid of planning solutions in spite of all the past approaches that have not curtailed the associated physical planning problems attributable to urban sprawl. This reinforces the fact that there is a need for the introduction of a dynamic strategy that would consider the peculiarities of Nigerian cities. The ineffectiveness in the use of master plan to curtail the spread of urban sprawl in Nigerian cities is not as a result of the unimproved "political will" to implement the provisions of the master plan alone but the financial requirements to prepare and implement master plan are not readily available. The solution therefore, readily lies with the people (i.e. the developers). All that is required is to guide the people through the use of effective advocacy in their physical development activities.

Therefore, State Urban and Regional Planning Board (as designated in the Nigerian Urban and Regional Planning laws) or the agency saddled with the responsibilities in the state need to adopt the approach of "planning with the people" and not necessary "planning for the people" with a view to collaborate the people's efforts with that of the government in their physical development bids. This might be qualified and described as Public-Private Partnership (PPP) in physical development planning of Nigerian cities with a focus at checking urban sprawl.

The use of advocacy in the enlightenment of the communities and land-owners residing at the city suburbs is to see their relevance in accepting sound physical planning principles. The Chief Executive Officers of the Local Planning
Authorities at their various local government areas of their jurisdiction should identify parcels of land at different locations in the suburbs of cities and towns for development under this approach. Rather than the owners of such parcels of land developing them as illegal structures and the Executive Officers of the Local Planning Authorities scaring them with demolition notices that are never enforced; arrangement of meetings with the land-owners at educating them on the need for the development of their land in harmony with planning regulations should be embarked upon.

Even when the land-owners do not have the money, either to pay for the cost of carrying out the perimeter surveying or the cost of laying out (i.e. sub-dividing) the parcels of land into plots; the Chief Executive Officers of the Local Planning Authorities should facilitate arrangement between the land-owners and relevant individual professional firms that would render the required services in the preparation of the layout plans. The arrangement is to ensure that these services are rendered on the understanding that an agreed number of building plots would be released to the professionals in returns for their services.

The advantages of this approach are in three folds. First, the inability of most communities and families to pay the professional fees for both surveying and laying out their parcels of land, due to high poverty level would be completely avoided. Second, the approach would promote physical development of the city-suburbs in line with the provisions of planning regulations as well as enhance the financial value of their land.

This will encourage many communities and families to come out openly to participate in the physical development of their land, rather than outright acquisition of their land by government on which compensations are not paid and for which such land plots are not readily developed by the government. Besides all these, the approach gives land-owners and communities a sense of belonging and it energizes communities to embrace physical planning. It will equally allow for the effective use of development control in the laid out areas and ensure that the involvement of the communities in the provision of infrastructure gains wider acceptance.

However, it becomes expedient to sound a note of warning to the Chief Executive Officers of the Local Planning Authorities that their involvement in the facilitation of this arrangement should not be on the premise of exploiting the 
communities or the land-owners of their financial benefits but essentially to ensure that the city suburbs are well-planned. Nonetheless, the approach cannot be completely insulated from abuse by greedy Chief Executive Officers and other Urban and Regional Planning Officers working in the Local Planning Authorities but a close monitoring of the planning activities by the State Urban and Regional Planning Board would eliminate possible abuse. In case of any abuse, erring officers found wanting should be prosecuted under relevant laws of the land, especially under the anti-corruption laws.

\section{TOWARDS ACHIEVING SUSTAINABLE CITY DEVELOPMENT IN NIGERIA}

Urban environmental problems in Nigeria are multi-faceted and are associated with the colonial antecedents of Nigerian cities, urbanization and issues that come with developmental challenges, urban production and consumption patterns and psychological orientation of urban residents as well as institutional failures. These problems pose serious environmental, economic and social challenges to achieving sustainable development in the country.

From all indications, various administrations in Nigeria-colonial, military and civilian placed very little importance on environmental issues. The essence of sustainable management of environmental resources and their harmonious relation with nature have not been given adequate attention for decades. The lack of political will within the public sector to address environmental problems remains one of most intricate problems in the country. A typical example of this can be seen in the issue of end to gas flaring and oil spillage in the Niger Delta Region, where environmental problems due to oil exploration have inflicted tremendous damage on the ecosystem, health and livelihood of the people of this region.

In the face of increasing urban population, there is inadequate supply of housing and infrastructure for the teeming population; as a result, the existing infrastructure and housing are overstressed, while unsanitary living conditions characterized by filthy environment, unclean ambient air, stinky and garbage-filled streets and sub-standard houses continue to dominate the urban landscape in Nigeria.
The concentration of more people in urban areas of the country has brought more pressure on the land space for the production of food, infrastructure, housing and industrialization. This affects the carrying capacity of the environment as each additional person increases the demand on the infrastructure and natural system and as a result creating ecological imbalance which comes with adverse environmental consequences such as hazards and disaster. In this circumstance, attempts to address the situation are difficult and capital intensive, because rapidly growing population does not provide ample room for the introduction of new and innovative approaches to tackling the problems. This paper does not argue against population growth, its concern is rather that there should be a corresponding socio-economic growth.

The growing population in Nigeria is associated with negative economic growth, and this requires special attention. As vast majority of urban residents in Nigeria suffer from severe deficiencies in the supply of basic infrastructure and housing, industrial, mining and domestic activities generate dangerous level of air, land and water pollution, endangering human lives and causing serious damage to the ecosystem.

Statistics show that a majority of urban residents in the country fall within the low-income group. This income class is the most vulnerable group to prevalent environmental problems, such as diseases associated with lack of access to natural resources and basic urban services and pollution. They also suffer the consequences of absence of inappropriate urban planning and management systems, and thus live in disaster prone areas of the cities. These ultimately impacts on their quality of life, health, and consequently reduce their productivity and economic development capacity.

Cities are centers of economic growth - the brightest stars of human achievement. They energize the entire system. They also show how malfunctional our systems are 'black holes in the atmosphere'. They are centers of degradation and, in a way, swallow most of resources and affect areas larger than themselves.

In the social context, environmental problems pose serious threats to the social wellbeing of a majority of urban residents in Nigeria. Apart from general health implications of environmental problems, there are tendencies of problems affecting the psyche of the people. For instance, residents of urban slums are known to show de- 
viance attitudes, apathy to government programs and anti-social values (e.g. Prostitution, crimes, and juvenile delinquency). Most importantly, social indicators in Nigeria are something of a paradox. The country is rich in natural endowments but the people are living in abject poverty. This paradox is especially evident because the vast resources and windfall of oil wealth have not translated to enhance the quality of life. Statistics indicated that in 2003, on the highest scale of 1.0, Nigeria had Human Development Index (HDI) of 0.453 as compared to that of other oil producing nations such as United Arab Emirates, Kuwait, Libya, Venezuela, and Indonesia which had the HDI values of $0.800,0.844,0.799,0.772$ and 0.697 , respectively [UNDP, 2006]. This is an indication of the poverty level and low life expectancy in the country.

Furthermore, environmental problems are inimical to social equity and welfare with respect to accessibility to social infrastructure and job opportunities. It is argued that urban poverty in Nigeria has strong links with underdevelopment and environmental degradation. Environmental problems have, for instance in the Niger Delta Region, resulted in a loss of job opportunities, increased poverty level, social exclusion and loss in cultural heritage. Many agricultural lands and fishing waters have been polluted, and the people are denied means of livelihood. As a result, a majority of the people feels reluctant to participate in economic development activities; instead they have chosen the part of militancy in the quest for resource control. The inability of Nigerian cities to cope with increasing environmental challenges has also shown manifestation in poor economic growth and development. Rapid growth of cities due to urbanization has led to the emergence of low-income informal settlements both in the inner-city and on the outskirts. This development accounted for the over bloated informal sector. The domination of the national economy by the informal sector that is characterized by subsistence economic activities known for low productivity and income, operating in unregulated and uncompetitive markets outside government approved guidelines has far-reaching implications for sustainable economic development. A large proportion of businesses operating in informal settlements in urban areas in Nigeria pay hardly any taxes, have no financial records, do not form part of government statistical records, and have limited or no access to formal credit services.
Coupled with an inefficient infrastructure network and unwholesome operating environment, industrial production is low, while manufacturing continues to contribute less than 15 percent of the gross domestic product (GDP) in Nigeria. Consequently, Nigeria's major development challenges which have to do with acceleration of economic growth, reduction of the level of poverty and improvement of environmental quality continue to grow unabated, and thus achieving the Millennium Development Goals (MDGs) by 2015 and beyond in the country is a mirage.

Urban and rural population will be increasingly interdependent for their economic, social and Environmental wellbeing in Nigeria. By 2015, more than half of the country's population is expected to live in urban centers. With an urbanization rate of about 5.5 percent per annum [Nwaka, 2005], it is anticipated that the urban population would have reached 65 percent of the total population. Therefore, unless appropriate actions are taken, environmental decay is set to rise, and this poses serious threat to sustainable development because Nigeria's economy and society largely depends on its ecology for food production, power generation and source of raw materials for industrial activities.

\section{RECOMMENDATIONS FOR ACHIEVING SUSTAINABLE CITY DEVELOPMENT IN NIGERIA}

The NEPAD initiatives, National Economic Empowerment and Development Strategies (NEEDS) and Vision 2020 have gradually embraced a new concept of sustainable development in the face of rapid urbanization and increasing environmental problems in Nigeria. These strategies embrace relationship between all human settlements, from small urban centers to metropolises, and between towns and cities and their surrounding rural areas. As intractable as these approaches may appear, they are potent, dynamic and desirable forces for development. For these initiatives to produce the desired impact in Nigeria, they must adopt strategies that would make significant impact on problems and issue related to urbanization, attitudinal orientation and lapses in legal and institutional frameworks in environmental management.

Based on these, this report offers the following suggestions in addressing these issues: 
- Rural - Urban migration remains one of the major contributors to the ever increasing urban population growth in Nigeria; this is probably due to the perceived wide gap between the urban and rural areas in terms of job opportunities and availability of basic infrastructural facilities. This infrastructure gap has to be bridged through comprehensive rural infrastructure provision. There is an urgent need for the government to enter into partnerships with Community-Based Organizations in rural infrastructure provision. This will promote the establishment of agro based industries, provide incentives for younger people to go into agricultural activities and make life worth living in rural areas. These will eventually reduce the number of immigrants to the urban areas and consequently cut down on the rate of urban population growth.

- Increasing the environmental carrying capacity is necessary for enhancing the livability of urban areas in Nigeria. Massive rehabilitation and expansion of urban infrastructure stock in the country should be taken more seriously. Collaborative efforts among all stakeholders in taking advantage of the existing economies of scale in our urban areas in improving the infrastructure stock are inevitable. The concept of Public-Private Partnerships (PPPs) in the provision of urban infrastructure should be adopted. Slum areas in urban areas in the country should be revitalized, or remodeled through the introduction of basic infrastructure services and incorporation of mix-use development to enhance property values, and thus checking further deterioration of such areas.

- Remodeling of urban transport system from automobile-based to pedestrian, bicycle and mass transit (e.g. intra-city and inter-city) systems is a worthwhile venture. This will reduce the level of dependence on single-passenger automobiles, and consequently reduce the problems of air pollution, traffic congestion and high energy consumption. The imposition of special tax on private cars in certain parts of cities like Lagos, Port Harcourt, Abuja, Kano, Ibadan, Enugu and other major cities at various times will definitely help to achieve this objective. Furthermore, appropriate legislations should be put in place to check indiscriminate discharge of industrial wastes (gas, liquid, solid), while the relevant regulatory institutions and agencies should be empowered to monitor the level of compliance and mete out appropriate sanctions to offenders.

- The provision of both closed storm water drainage (curbs, gutters, catch basins, underground pipes, culverts, inclined channels) and open drain systems (swales, filter strips) as adequate monitoring of physical developments will check perennial urban flooding in Nigerian cities. Development along flood plains, drainage channels infrastructure easements and flood prone areas should be avoided. Development Control Authorities (e.g. Town Planning and Capital City Development Authorities) should enter into partnerships with the private sector to ensure that physical development legislations are strictly adhered to by developers.

- Plants have been found to be beneficial to man not only as food but also as natural source of oxygen. In addition, they provide shades from sun, beautify the environment and protect the soil from erosion. To maximize these benefits, there is a need to increase the number of the green areas and open spaces in urban areas by encouraging the preservation of green areas and open spaces. For these reasons, the annual tree planting exercise, agro forestry, and community-based conservation schemes should be taken more seriously, and people should be encouraged to plant trees, ornamental plants and establish horticulture gardens around their buildings. While the use of hard landscaping element around buildings, bush burning and illegal mining activities should be discouraged.

- Going by the level of construction activities that go on in this country, there is a need for effective monitoring by the relevant authorities of every construction activity to make sure that such does not have adverse effects on the environment within, around or distance from the construction site. The relevant provisions dealing with this issue in the Environmental Impact Assessment (EIA) Act 86 of 1992 should be strictly enforced. Also, the construction industry needs to imbibe the concept of "green/eco-construction" in devising new methods and develop new materials that are not injurious to the environment and does not constitute health hazards.

- Solid waste management in urban areas seems to have engaged the attention of government at all levels in Nigeria. Despite the establishment 
of waste management agencies, the problem of solid waste management persists in urban areas in the country. Therefore, Public-Private Partnership or outright privatization of urban waste management activities should be explored. By this arrangement, private organizations should be involved in house - to-collection and disposal of refuse at the expense of the households. The establishment of waste treatment or recycling plants and the use of the products for agricultural purposes should be looked into.

- It is argued that Nigeria never lacked good policies, legislations and institutional frameworks but good implementation has always been the crux of the matter. The failure of existing laws and institutions to make significant impacts in protecting and preserving the environment may be have been due to poor legal frameworks, poor funding and lack of adequate manpower. Therefore, the reorganization of environmental management institutions has become most expedient. This ensures horizontal and vertical coordination among the institutions. Similarly, all legal ambiguity, lack of qualified personnel, inadequate funding should be addressed. The private sector should be encouraged to make significant contributions in capacity building in environmental management institutions. This will enhance the capacity of the institutions to enforce environmental laws and physical development regulations, and thus reducing the rate of illegal developments, contravention of planning laws, street trading and indiscriminate dumping of refuse in unauthorized places.

- The psychological re-orientation of the people toward proper environmental management practices is central in developing environmental consciousness in individuals. To this end, environmental education such as public enlightenment campaigns in the mass and print media, churches, mosques, and communitybased organizations is highly needed. Similarly, the introduction of environmental studies into the curriculum of the educational system at all levels will most likely contribute to creating the desired environmental awareness, and thus reducing unfriendly environmental practices (e.g. indiscriminate dumping of refuse on the roads, drains and unauthorized locations, defecating in the open field) in Nigerian cities.
- Built environment professionals (e.g. architects, urban planners, estate managers, builders, engineers, etc.) have a role to play in creating environment that does not jeopardize peoples' health and well-being'. They should accept the responsibility of being the "watch dog" over the environment in making sure that they use their professional expertise to protect the environment for the present and future generations. Through appropriate design, construction and management solutions, significant result in environmental sustainability and by extension sustainable development can be achieved.

\section{CONCLUSIONS}

Urban environmental problems are of different dimensions and are mostly due to geologic, climatic and cultural factors. However, the cultural factors seems to be more pronounced in the Nigerian context because most of the identified urban environmental issues are so much associated with the way of life of the people either as reactions to urbanization or their spatial heritage. Their effects are far reaching on efforts to attain sustainable development in the country. Since no section of the country's urban environment is immune to environmental effects, there is urgent need to seek workable solutions by the application of planning, economic, legal, institutional and educational tools as have been suggested here. One basic factor that is essential to successful implementation of planning project is to embrace sound planning practice that is based on evolving principles. It is time for city dwellers particularly in Nigeria and other developing countries to note that government resources are limited and its areas of attention are unlimited. This has made the need for collaboration between government and the public in curtailing urban sprawl. Therefore, the strategy of planning with the communities in a bid to check urban sprawl as suggested would go in no small measure at enlisting the support of the developers.

It is hoped that if these tools are properly adopted it will result in the enculturation of the right environmental management practices that would prevent the further deterioration of our physical urban environment; hence the possibility of achieving sustainable development in Nigeria in the nearest is assure. 


\section{REFERENCES}

1. Abiodun O. 1985. Urban and regional planning problems in Nigeria. Ife, University of Ife Press.

2. Acho C. 1998. Human interference and environmental instability: Addressing the environmental consequences of rapid urban growth in Bamenda, Cameroon. Environment and Urbanization, 10(2), 161-174.

3. Adedeji Y.M.D. 2005. Sustainable low-cost housing technology in cities: Accelerated construction initiative option. Journal of Land Use and Development Studies, 1(1).

4. Afolayan A.A. 1978. Population. In: Oguntoyinbo J.S., Areola O.O. and M. Filani (Eds.) A geography of Nigerian development. Ibadan: Heinemann Educational Books Nigeria Limited, 113-123.

5. Agbola T. 2004. The Nigerian urban development policy: If the past be prologue. Paper presented at the $34^{\text {th }}$ Annual Conference of the Nigeria Institute of Town Planners at Abeokuta, October 22 to 24, 2004.
6. Agbola T. 2006. Sustainable urbanisation and the new urban planning: Dilemma of new opportunities and the challenges for Nigeria technocratic planners. A paper presented at the 2nd Postgraduate Diploma Regular Forum, lecture series in the Dept. of Urban and Regional Planning, Rufus Giwa Polytechnic, Owo, 3rd June, 2006.

7. Donk V.M. 2006. Positive urban futures in Subsaharan African: HIV/AIDS and the need for a broader conceptualisation (ABC). Environment and Urbanisation, 18(1), 155-177.

8. Farunkanmi O. 2003. Controlling urban sprawl through effective urban governance. A paper presented at the monthly meeting of the Ondo State Chapter of Nigerian Institute of Town Planners, Akure, on March 27, 2003.

9. Ogbazi J. 1992. Historical development of urban planning in Nigeria. In: H. Chike Mba et. al. (Eds.) Principles and practice of urban and regional planning in Nigeria, Awka, Mekslink publishers (Nig.) 12-19. 